\section{LABORATORY ANd Statistical Evaluation of CeMENT and Lime on the Properties of Tropical Black Clay - IRON ORE TAILINGS MiXTURES}

\author{
Yohanna, P. ${ }^{a}$, Buki, J. M. ${ }^{b}$, Ijimdiya, T. S. ${ }^{b}$, Eberemu, A. O. ${ }^{b}$, Osinubi, K. J. ${ }^{b}$ \\ aDepartment of Civil Engineering University of Jos, Nigeria \\ ${ }^{b}$ Department of Civil Engineering, Ahmadu Bello University, Zaria, \\ Nigeria.
}

Article history Received

18 July 2020

Received in revised form 8 September 2020 Accepted 10 September 2020 Published online 30 November 2020

*Corresponding author paulyohanna45@yahoo.co.uk

\begin{abstract}
The need for cheaper and more economical soil improvement methods is of great significance in order to reduce the construction cost of flexible pavements. Also, major problems caused by industrial waste in Nigeria can be minimised by recycling or re-using of such wastes for soil improvement. The application of cement and lime along for such purpose has proven to increase the construction cost. Thus the use of industrial waste such as iron ore tailings (IOT) could aid in reducing the construction cost. Series of laboratory and statistical investigations were performed to compare the effect of cement and lime on the properties of tropical black clay (i.e. black cotton soil, BCS). Soil samples were admixed with up to $10 \%$ IOT content and modified with up to $4 \%$ each of cement and lime by dry weight of soil to evaluate their plasticity and compaction characteristics. Compaction was done with British Standard light (BSL) energy. Statistical tests for regression and correlation was achieved using Mini-tab R15 and Microsoft Excel software correspondingly. Results disclosed decreased in liquid limit and plastic limit. Liquid limit values of 56, 54.8, 54.5, 52.5, 52 and $51 \%$ were noted for $0,2,4,6,8$ and $10 \%$ IOT content. Similar trend was noted for 1, 2, 3 and $4 \%$ lime and cement concentrations. A rise in maximum dry density (MDD) and drop in optimum moisture content (OMC) with greater concentration of IOT for all the lime and cement contents under study was noted. Statistical analysis revealed that soil-lime-IOT mixtures gave higher predicted values than soil-cement-IOT mixture for determining plasticity and compaction characteristics of BCS - IOT mixtures. Thus, $4 \%$ lime $-6 \%$ IOT mixture met the criteria for flexible pavement purpose as proposed by Nigerian General Specifications and is recommended for used as pavement material for roads that are lightly trafficked. While the soil - cement - IOT mixes fell to meet the criteria for used as pavement material.
\end{abstract}

Keywords: Black cotton soil, Cement, Compaction characteristics, Correlation analysis, I ron ore tailings, Lime, Regression analysis

C 2020 Penerbit UTM Press. All rights reserved

\subsection{INTRODUCTION}

Black cotton soils (BCS) are not suitable materials to utilize for highway construction due to their high percentage of plastic clays: high volume changes with permeability as well as low shear strength [1-5]. Most times areas where they are found available are most shot of suitable aggregates or gravels. BCS cover considerably large regions that escaping them is not promising [6]. Alternative improved soils appropriate for construction are most times not easy to get and hence improving such soils are of great commercial significance to industry involved in construction. The geotechnical properties of black cotton soils cannot satisfy the strength and incompressibility requirements for engineering purposes.
Therefore, road construction over deficient soils causes a major challenge in road construction. In a demand to make this soil valuable for pavement purposes and satisfy the criteria for foundation engineering intentions, its geotechnical properties need to be improved. The modification of the soils plasticity and compaction properties is familiar to engineers as a key process of enhancing the performance of challenging soils and pave way for marginal soils become better civil engineering materials [7].

Excessive need for conventional soil enhancing additives (cement, lime, bitumen, etc.) has raised construction cost too high for stabilized roads [8]. Researchers worked to obtain cheaper additives for soil improvement which can be used as substitutes for the expensive industrially manufactured soil 
improving additives. This challenge headed to using agricultural wastes such as bagasse ash [9], locust bean waste ash [10], rice husk ash [11] and industrial waste such as fly ash [12], cement kiln dust[13] and is iron ore tailings [14-16] that have pozzolanic properties.

Mine tailings is an industrial by-product which is produced in huge quantity from mining industries after extraction of minerals from pyretic ores and poses disposal problems and also creates environmental hazard. In recent periods, there is an upsurge in utilization of mine tailings for geotechnical use, so long as they are admixed with some admixtures such as cement and lime since they are low in $\mathrm{CaO}$. The Itakpe iron ore generate a lot of tailings and is a popular mine tailings in Nigeria rich in hematite-rich mineral. The large deposit of the waste led to the need to look for a way of safe disposal of this waste by re-using it in the construction industry. By this approach, the environment is safe from pollution and also minimizes the construction cost.

The study was aimed at comparative influence of cement and Lime mixtures on the plasticity and compaction characteristics of BCS using IOT as admixture. The objective was to check the alterations in the soil plasticity and compaction characteristics when used as road construction materials.

\subsection{MATERIALS AND METHODS}

\section{$2.1 \quad$ Materials}

Soil: Disturbed sample was gotten from Gombe state, Nigeria, with geographical coordinates Longitude $11^{\circ} 30^{\prime} \mathrm{E}$ and Latit u de $10^{\circ} 19^{\prime} \mathrm{N}$. The soil samples were air-dried and passed through $4.76 \mathrm{~mm}$ aperture sieve prior test.

Cement: The ordinary Portland cement (OPC) used was purchase in local market in zaria.
Lime: The Lime used was purchase in local market in zaria.

Iron Ore Tailing: The iron ore tailing (IOT) used was collected from Itakpe National Mining Ore Company in Kogi state.

\section{$2.2 \quad$ Methods}

Index Properties: Laboratory tests were carried out on the natural soil and treated soil in accord with [17] and [18], correspondingly. Soil samples were mixed with $0,1,2,3$ and 4 $\%$ cement and lime, respectively, as well as $0,2,4,6,8$ and 10 $\%$ IOT by dry weight of soil.

Compaction: Compaction was done for both natural and treated soil based on [17] and [18] with BSL energy. Test comprises a $2.5 \mathrm{~kg}$ rammer falling $300 \mathrm{~mm}$ in three layers in a British Standard mould, each getting twenty seven (27) blows. Test was done for the varying additives mixtures.

Statistical Analysis: Laboratory tests on plasticity and compaction characteristics and the factors associated with plasticity and compaction characteristics were obtained from laboratory tests. Factors measured include; Maximum dry density of lime-IOT treated soil (MDDL), Maximum dry density of cement-IOT treated soil (MDDC), Optimum moisture content of lime-IOT treated soil (OMCL) and Optimum moisture content of cement-IOT treated soil (OMCC) as dependent factors and Gravel content(Gr),Sand content(Sa),Percentage of fine(PF i.e proportion of silt and clay),Plasticity index(PI), Specific gravity(Gs), Lime content(Li), Cement content(Ce) and Iron ore tailings content(IOT) as independent factors. A regression model, for predicting MDDL, MDDC, OMCL and OMCC was developed. The statistical studies were done using Mini-tab R15 software. Pearson correlation coefficients was carried out using Microsoft Excel 2007.The Means, standard deviation and coefficient of variation for compaction characteristics and measured parameters are shown in Table 1.

Table 1 Comparative descriptive Statistics for Compaction Characteristics of Lime and Cement Treated BCS with IOT as Admixture.

\begin{tabular}{lrrr|llrr}
\hline Variable & Mean & SD & CV & Variable & Mean & SD & CV \\
\hline MDDL & 1.607 & 0.030 & 1.848 & MDDC & 1.607 & 0.038 & 2.383 \\
OMCL & 22.420 & 0.920 & 4.103 & OMCC & 20.693 & 1.487 & 7.186 \\
Gr & 1.047 & 0.929 & 88.730 & Gr & 1.377 & 0.847 & 61.511 \\
Sa & 21.291 & 4.038 & 18.966 & Sa & 24.510 & 6.290 & 25.663 \\
PF & 77.662 & 4.065 & 5.234 & PF & 74.110 & 6.720 & 9.068 \\
PI & 27.953 & 1.176 & 4.207 & PI & 35.067 & 2.224 & 6.342 \\
Gs & 2.519 & 0.044 & 1.735 & Gs & 2.549 & 0.035 & 1.365 \\
Li & 2.000 & 1.438 & 71.900 & Ce & 2.000 & 1.438 & 71.900 \\
IOT & 5.000 & 3.474 & 69.480 & IOT & 5.000 & 3.474 & 69.480 \\
\hline
\end{tabular}




\subsection{RESULTS AND DISCUSSION}

\subsection{Index Properties}

Tests performed on the soil showed that it is fine-grained with greyish-black colour and moisture content of $19.5 \%$. The soil is grouped as A-7-6(24) using [19] and $\mathrm{CH}$ using [20].The summarized properties are given in Table 2 . The oxide composition is given in Table 3 . The particle size curve is displayed in Figure 1

Table 2: Natural Soil Properties

\begin{tabular}{lc}
\hline Property & Quantity \\
\hline $\begin{array}{l}\text { Natural moisture } \\
\text { content, \% }\end{array}$ & 19.5 \\
Percentage & 82.0 \\
passing BS No. 200 & \\
sieve & \\
Liquid Limit, \% & 56.0 \\
Plastic Limit, \% & 27.0 \\
Plasticity Index, \% & 29.0 \\
Linear Shrinkage, & 18.4 \\
\% & \\
AASHTO & A-7-6(24) \\
Classification & \\
USCS Classification & CH \\
Swelling Potential & Medium \\
Specific Gravity & 2.47 \\
MDD, Mg/m & 1.58 \\
OMC, \% & 23.0 \\
Colour & Greyish - black \\
\hline
\end{tabular}

Table 3: Oxide compositions of OPC, Lime and IOT

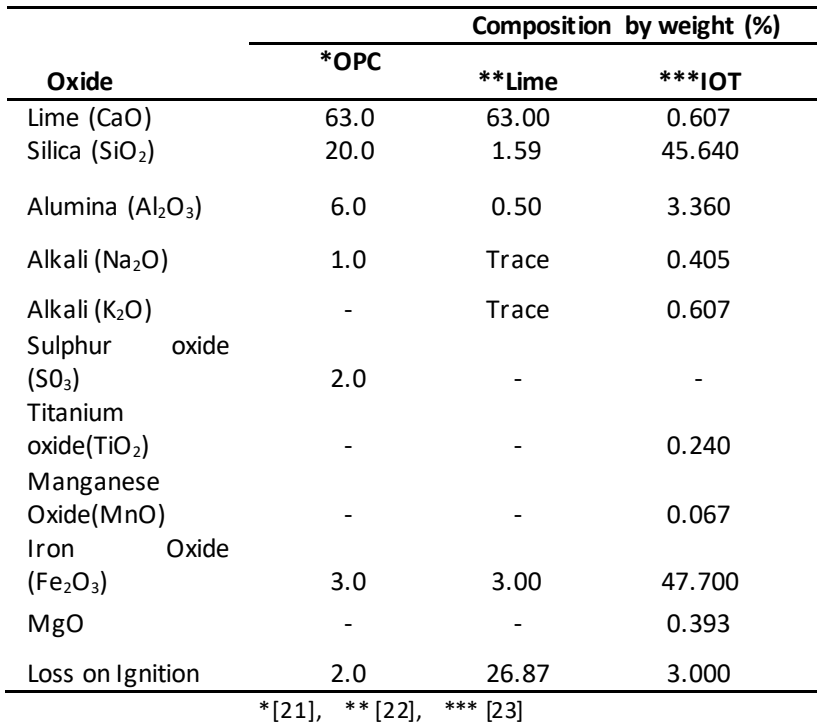

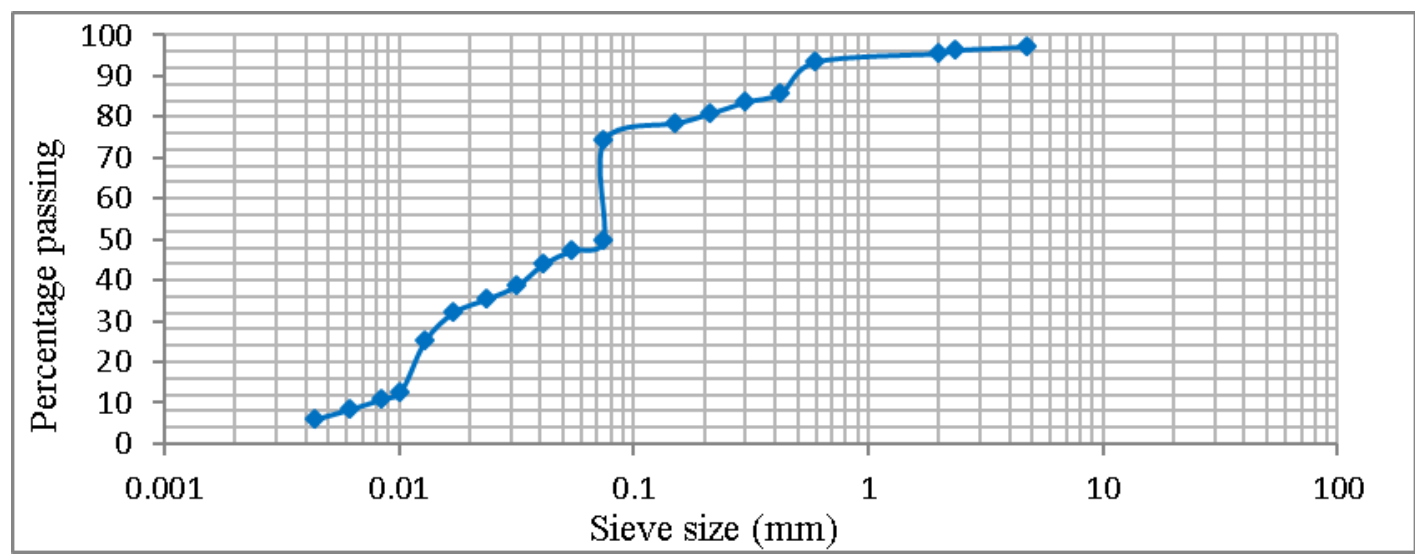

Figure 1 Particle size curve of natural soil

\subsection{Effect of Cement and Lime - IOT Blend on the Plasticity Characteristics of BCS}

\subsubsection{Liquid Limit}

The variations of liquid limits (LL) of the soil - lime and soil cement mixes with IOT content are displayed in Figure $2 \mathrm{a}$ and
$2 b$, separately. The $L L$ for the natural soil decreased steadily with rise in IOT content. LL of the natural soil lessened with higher lime, cement and IOT contents (see Figure $2 \mathrm{a}$ and $2 \mathrm{~b}$ ). LL values of $56,54.8,54.5,52.5,52$ and $51 \%$ were noted for 0,2 , $4,6,8$ and $10 \%$ IOT content. Similar trend was noted for $1,2,3$ and $4 \%$ lime and cement concentrations. However, lower results were recorded with lime treatment than cement 
treatment which indicates that lime is more potent than cement because lime creates a fast and extensive chemical reaction with soil elements than cement [24]. The drop in LL with higher contents of the additives could be linked to the decline of free silt and clay fractions in the soil due to flocculation and agglomeration of the clay particle as a result of ion exchange at the soil surface of the clay particle as the

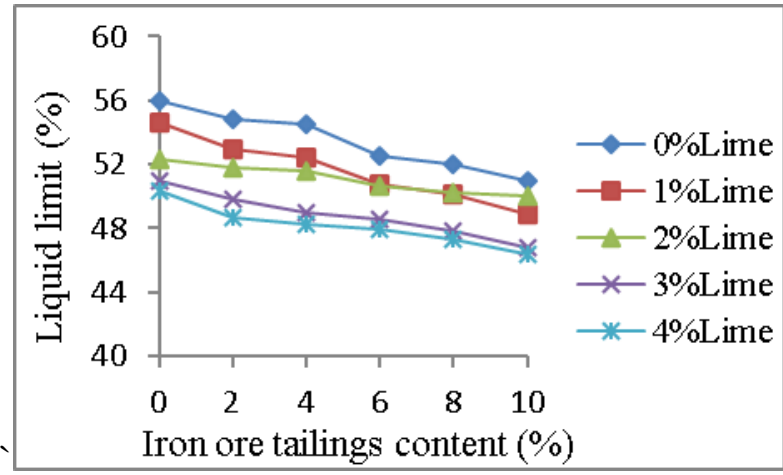

Figure. 2a Graph of liquid limit of BCS-lime mixes with IOT content

\subsubsection{Plastic Limit}

The variations of plastic limit of soil - lime mixes and soil cement mixes with IOT content are displayed in Figure $3 a$ and $3 b$, respectively. Generally, for lime and cement treatments, the plastic limit drop with rise in IOT content. Plastic limit values of $26.4,24.7,24,22,21.4$ and $20 \%$ were noted for $1 \%$ lime and $0,2,4,6,8$ and $10 \%$ IOT content. Also values of 22.2,

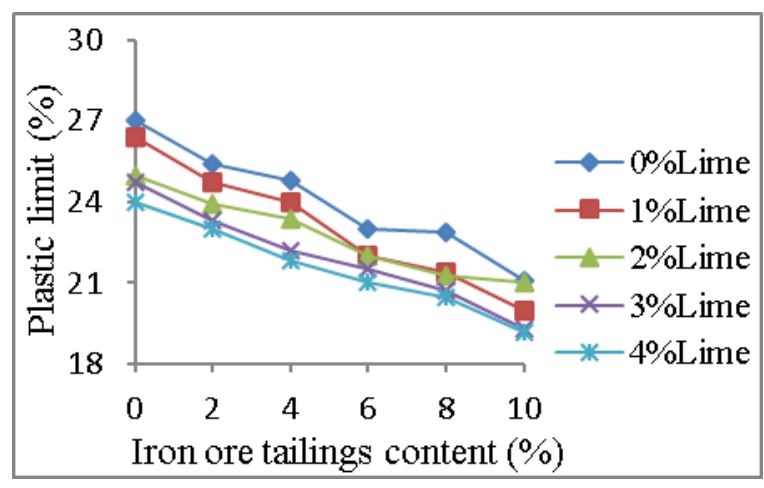

Figure 3a Graph of plastic limit of BCS -lime mixes with IOT content

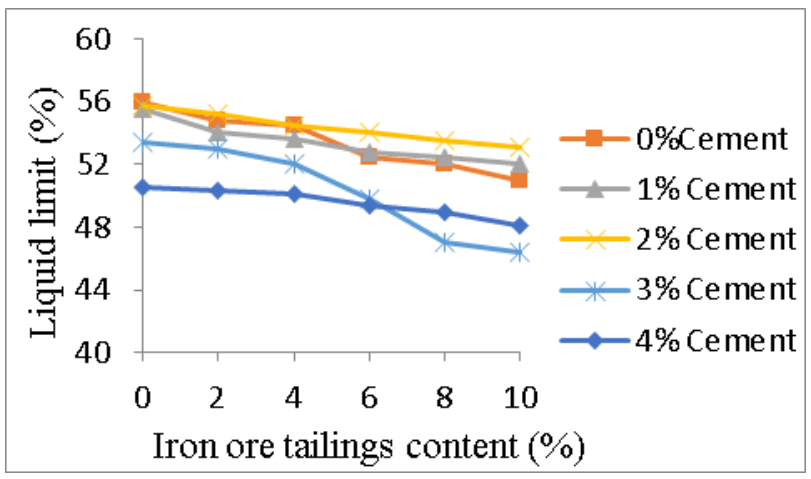

Figure. $2 b$ Graph of liquid limit of BCS - cement mixes with IOT content

$20.5,20,18.18,17.14$ and $16 \%$ were noted for $1 \%$ cement and $0,2,4,6,8$ and $10 \%$ IOT content. Same trend was noted for higher concentrations of lime and cement. The decreases in plastic limit recorded may perhaps be linked to cation exchange reaction that released adsorbed water particles in the soil that led to flocculation and aggregation. Similar trends were reported by $[6,15,27]$.

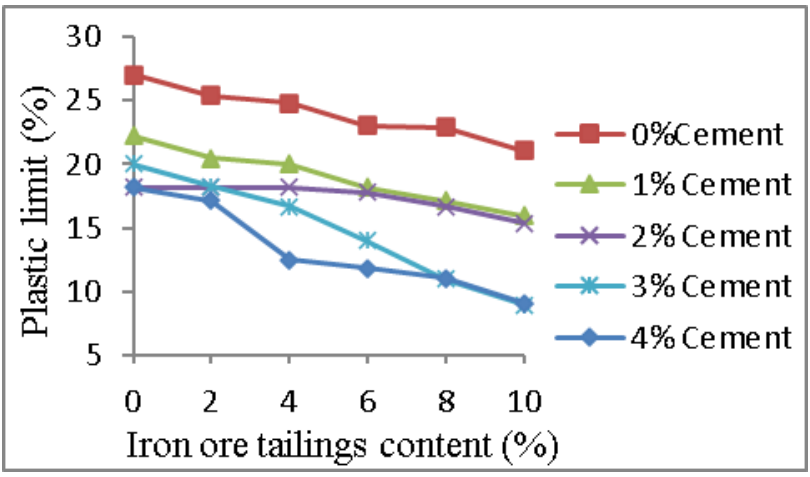

Figure 3b Graph of plastic limit of BCS -cement mixes with IOT content

\subsubsection{Plasticity Index}

The variations of plasticity index of soil - lime and soil - cement mixes with IOT content are displayed in Figure $4 \mathrm{a}$ and $4 \mathrm{~b}$ individually. Plasticity index of the mixtures generally increased with increase in IOT content. Plasticity index values of 28.2, $28.3,28.4,28.8,28.7$ and $28.9 \%$ were noted for $1 \%$ lime and 0 , $2,4,6,8$ and $10 \%$ IOT content. Also values of 33.28, 33.50, $33.60,34.62,35.36$ and $36 \%$ were noted for $1 \%$ cement and 0 , available $\mathrm{Ca}^{2+}$ in the admixtures reacted with the metallic ion in the clay structure $[6,25-26]$. 


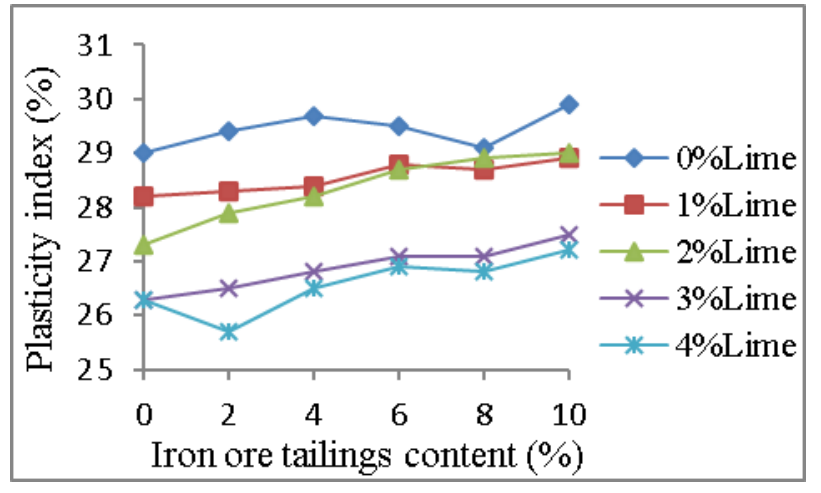

Figure 4a Graph of plasticity limit of BCS -lime mixes with IOT content

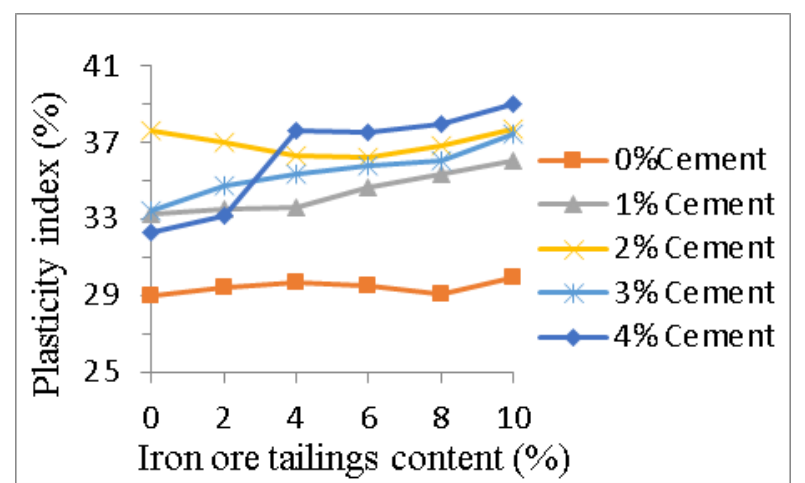

Figure $4 \mathrm{~b}$ Graph of plasticity limit of BCS -cement mixes with IOT content

\subsection{Effect of Cement and Lime - IOT Blend on the Compaction Characteristics of BCS}

\subsubsection{Maximum Dry Density}

The variations of MDD of BCS - lime and BCS - cement mixes with IOT content are displayed in Figure $5 \mathrm{a}$ and $5 \mathrm{~b}$, respectively. The general increase in MDD values of soil treated with lime and cement increased with higher IOT content may perhaps be linked to IOT with greater specific gravity (3.29) filling the voids inside the soil medium and also, the flocculation and accumulation of the clay particles due to ion exchange

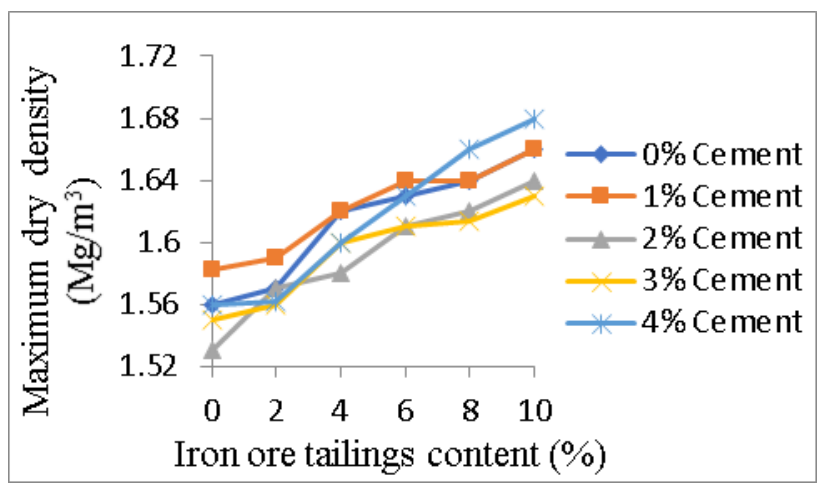

Figure 5a Graph of MDD of BCS -lime mixes with IOT content

\subsubsection{Optimum Moisture Content}

The variations of OMC of BCS - lime and soil - cement mixes with IOT content are displayed in Figure $6 a$ and $6 \mathrm{~b}$, separately. Generally, OMC of the two mixes considered decreased with rise in IOT content. OMC values of 23.8, 23, 22.5, 22.2, 22 and $21.4 \%$ were noted for $2 \%$ lime and $0,2,4,6,8$ and $10 \%$ IOT content. Also values of 22.6, 22.4, 22.2, 22, 20.8 and $19 \%$ we re noted for $2 \%$ cement and $0,2,4,6,8$ and $10 \%$ IOT content. Same trend was noted for other concentrations of lime and cement content. Similar trend of decrease in OMC values was recorded by [33].The introduction of IOT into the mixtures could have supplied calcium cations that cause low and incomplete hydration reaction thus reducing the OMC. However, the values increased with greater lime content that may possibly be attributed to the rise in the volume of water
[15,26,30-32]. MDD values of 1.57, 1.59, 1.62, 1.63, 1.64 and $1.64 \mathrm{Mg} / \mathrm{m}^{3}$ were noted for $1 \%$ lime and $0,2,4,6,8$ and $10 \%$ IOT content. Also values of 1.58, 1.59, 1.62, 1.64, 1.64 and 1.64 $\mathrm{Mg} / \mathrm{m}^{3}$ were noted for $1 \%$ cement and $0,2,4,6,8$ and $10 \%$ IOT content. Same trend was noted for higher concentrations of lime and cement content. The higher MDD values recorded for soil - cement mixes compared to soil - lime mixes is linked to the fact that cement is more denser than lime when compared, hence cement having higher weight and specific gravity than lime, Hence the higher MDD values. Similar trend of increase in MDD values was recorded by [33].



Figure 5b Graph of MDD of BCS -cement mixes with IOT content

necessary for pozzolanic reaction to occur. On the other hand, the reduction in OMC values observed for 3 and $4 \%$ cement contents was probably linked to dehydration induced by the addition of IOT into the soil voids that were initially fille d with moisture and air within the soil mass. In this case, no water migration to or from soil-IOT-cement matrix is allowed, the available water was consumed by the hydration reaction, till too little was left to saturate the solid faces and thus a de cline in soil relative humidity $[15,26,34-35]$. The implication of moisture control during field compaction is a very important factor that has to be put into consideration. The number of passes of the compaction machine and the desire field density that need to be attained relative to the laboratory measured value can only be achieve via proper moisture control in the field. This in addition to achieving the Nigerian General Specifications criteria [36]. 


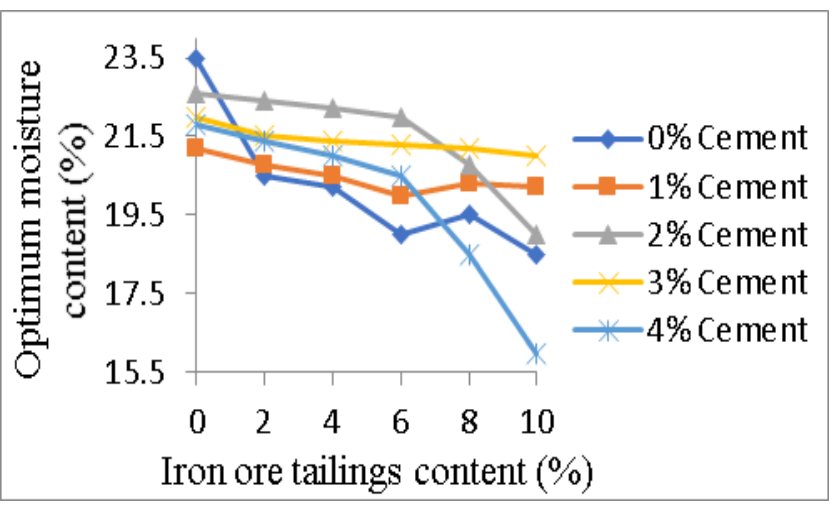

Figure 6a Graph of OMC of BCS -lime mixes with IOT content

3.4 Comparative Statistical Analysis for Compaction Characteristics of Lime and Cement Treated BCS with IOT as Admixture.

\subsubsection{Regression Analysis}

The application of regression and correlation techniques for engineering analysis has been reported by researchers [37-38]. Results of multiple regression analysis for MDDL and MDDC are contained in equation 1 and 2 respectively. The MDD for both lime and cement treated soil were subjective to the soil grading properties, specific gravity and the amount of admixture adde $d$ to the soil during experiment. The geotechnical factors measured for these analysis consist of the percentages of gravels, sand, plasticity index, lime/cement content, percentage fine,(proportion of silt and clay) in conjunction with their corresponding specific gravities. The coefficient of each factor in the regression equations shows the degree of affiliation between the MDD (dependent factor) and the soil geotechnical properties (independent variables) for all the treatments considered. Generally, sand content, percentage fine (proportion of silt and clay), specific gravity and IOT content has the point peak effect on the MDDs with a positive coefficient with others having negative coefficient for both MDDL and MDDC. However it was noticed that cement treated soil has higher coefficients for sand content and IOT over lime treated soil this can be linked to higher specific gravity of cement over lime filling the empty spaces inside the soil skeleton.

The correlation coefficient values $\left(R^{2}\right)$ displays a strong affiliation between MDDL, MDDC and the geotechnical factors considered with $\mathrm{R}^{2}$ values of $95.4 \%$ and $85.2 \%$ for MDDL and MDDC respectively. Generally, the correlation coefficient values shows that the factors are more correlated to the MDDL than MDDC. This implies that field compaction specification and control can easily and more reliable be monitored for BCS treated with lime and IOT than cement-IOT treated soil. The regression equations are

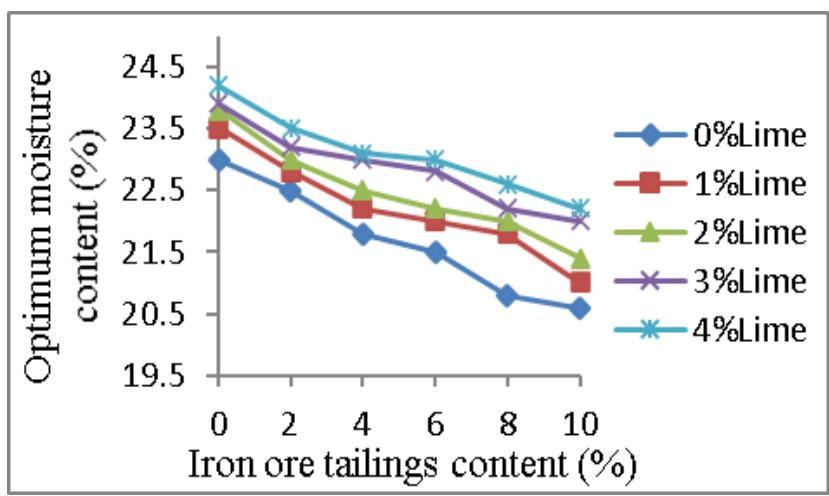

Figure $6 \mathrm{~b}$ Graph of OMC of BCS -cement mixes with IOT content

$$
\begin{aligned}
\mathrm{MDDL}= & 0.216-0.00081 \mathrm{Gr}+0.000330 \mathrm{Sa}+0.00 \mathrm{PF}-0.0029 \mathrm{PI}+0.582 \mathrm{Gs}- \\
& 0.00275 \mathrm{Li}+0.0008710 \mathrm{~T} \\
\mathrm{R}^{2}= & 95.4 \% \\
\mathrm{MDDC}= & 0.529-0.00417 \mathrm{Gr}+0.00143 \mathrm{Sa}+0.00 \mathrm{PF}+0.00128 \mathrm{PI}+0.391 \mathrm{Gs}- \\
& 0.0119 \mathrm{Ce}+0.0063310 \mathrm{~T} \\
\mathrm{R}^{2}= & 85.2 \% .
\end{aligned}
$$

Where;

MDDL=Maximum dry density of lime-IOT treated soil $\left(\mathrm{Mg} / \mathrm{m}^{3}\right), \mathrm{MDDC}=$ Maximum dry density of cement-IOT treated soil $\left(\mathrm{Mg} / \mathrm{m}^{3}\right), \mathrm{Gr}=$ Gravel content(\%), Sa=Sand content(\%), $\mathrm{PF}=\mathrm{Percentage}$ of fine(proportion of silt and clay), $\mathrm{PI}=\mathrm{Plasticity}$ index(\%), Gs=Specific gravity, Li=Lime content(\%), Ce=Cement content(\%), IOT=Iron ore tailings content(\%).

In the case of OMCL and OMCC, geotechnical factors measured for these analysis comprise the percentages of gravels, sand, plasticity index, lime/cement content, percentage fine, (proportion of silt and clay) together with their corresponding specific gravities. Results showed that sand content and lime content had more impact on $\mathrm{OMCL}$ with positive coefficient. However, for OMCC is significantly related to sand content and cement content with positive coefficient. The percentages of fine (proportion of silt and clay) have no impact on the OMCs of both treated soils.

The correlation coefficient values $\left(R^{2}\right)$ displays a strong affiliation between $\mathrm{OMCL}, \mathrm{OMCC}$ and the geotechnical factors considered with $\mathrm{R}^{2}$ values of $93.8 \%$ and $52.8 \%$ for $\mathrm{OMCL}$ and OMCC correspondingly. Generally, the correlation coefficient values shows that the factors are highly correlated to the OMCL than OMCC. This implies that field compaction specification and control can easily be monitored for BCS treated with lime-IOT than cement-IOT treated soil. In view of these reasons, a good approach of moisture control can easily be monitored using those variables during field compaction of soil-lime-IOT treate $d$ soil. The regression equations are; 
OMCL $=31.4-0.136 \mathrm{Gr}+0.0125 \mathrm{Sa}+0.00 \mathrm{PF}-0.017 \mathrm{PI}-3.28 \mathrm{Gs}+0.24 \mathrm{Li}-0.172 \mathrm{I} 0 \mathrm{~T}(3)$

$\mathrm{R}^{2}=93.8 \%$

OMCC $=73.0-0.025 \mathrm{Gr}-0.104 \mathrm{Sa}+0.00 \mathrm{PF}-0.09 \mathrm{PI}-18.5 \mathrm{Gs}+0.642 \mathrm{Ce}-0.125 \mathrm{IOT} \quad(4)$ $\mathrm{R}^{2}=52.8 \%$.

Where;

OMCL=Optimum moisture content of lime-IOT treated soil (\%), OMCC=Optimum moisture content of cement-IOT treated soil (\%).

\subsubsection{Correlation Analysis}

The coefficient of correlations between MDDs and geotechnical factors of lime and cement treated BCS with IOT are presented in table 4. Results showed that for MDD of lime-IOT treated soil, positive and highly significant correlations were obtained for gravel content, sand content, plasticity index, specific gravity and IOT indicating strong association between the factors and the MDDL. When compared with MDD of cementIOT treated soil, sand content, plasticity index, specific gravity and the IOT content showed strong affiliation between the factors and the MDDC.

Table 4 Pearson's Coefficients of Correlation for MDD and Geotechnical Properties of Lime and Cement Treated BCS with IOT.

\begin{tabular}{|c|c|c|c|c|c|c|c|c|}
\hline & MDDC & $\mathrm{Gr}$ & Sa & $\mathrm{PF}$ & $\mathrm{PI}$ & Gs & $\mathrm{Li}$ & IOT \\
\hline MDDL & - & 0.294 & 0.111 & $0.177^{-}$ & 0.619 & 0.979 & 0.382 & 0.877 \\
\hline Gr & -0.280 & - & $\begin{array}{r}- \\
0.086\end{array}$ & 0.143 & & 0.314 & 0.035 & 0.410 \\
\hline Sa & 0.079 & 0.458 & - & 0.974 & 0.293 & 0.049 & 0.222 & 0.104 \\
\hline PF & -0.039 & $\begin{array}{r}0.554 \\
-\end{array}$ & 0.994 & - & 0.288 & 0.121 & 0.229 & 0.197 \\
\hline $\mathrm{PI}$ & 0.365 & $\begin{array}{r}0.122 \\
-\end{array}$ & 0.200 & $\begin{array}{r}0.172 \\
-\end{array}$ & - & 0.651 & $\begin{array}{r}0.905 \\
-\end{array}$ & 0.311 \\
\hline Gs & 0.704 & 0.010 & 0.449 & 0.419 & 0.555 & - & 0.395 & 0.891 \\
\hline
\end{tabular}

\subsection{CONCLUSION}

The BCS is fine-grained fits into the $\mathrm{CH}$ group in the USCS and A-7-6(24) soil group in the AASHTO grouping method for soils. The plasticity of the BCS treated with lime and cement improved with higher IOT content. Generally, MDD increased while OMC declined with rise in IOT content. However, with increase in lime content, MDD drop while the OMC incre ased. On the other hand, for increased cement treatment, MDD values increased while OMC decreased with higher IOT content. Results of statistical analysis show that soil-lime-IOT mixture gave higher prediction values than soil-cement-IOT mixture for determining plasticity and compaction characteristics of tropical black clay - IOT Mixtures. This implies

\begin{tabular}{lrrrrrrrr} 
Ce & -0.090 & 0.297 & 0.650 & 0.646 & 0.580 & 0.530 & - & 0.000 \\
IOT & 0.908 & 0.261 & 0.004 & 0.029 & 0.513 & 0.764 & 0.000 & - \\
\hline Lower diagonal: MDDL=Maximum dry density of lime-IOT treated soil $\left(\mathrm{Mg} / \mathrm{m}^{3}\right)$, & \\
Upper diagonal: MDDC=Maximum dry density of cement-IOT treated soil \\
$\begin{array}{l}\left(\mathrm{Mg} / \mathrm{m}^{3}\right), \mathrm{Gr}=\mathrm{Gravel} \text { content(\%), Sa=Sand content(\%), PF=Percentage of } \\
\text { fine (proportion of silt and clay),PI=Plasticity index(\%), Gs=Specific gravity, Li=Lime } \\
\text { content(\%), Ce=Cement content(\%), IOT=Iron ore tailings content(\%). }\end{array}$
\end{tabular}

Coefficient of correlations between OMC and the geotechnical factors of lime and cement treated BCS with IOT, (see Table 5). Results show that for OMCL, positive and highly significant correlations were obtained for sand content, percentage fine and lime content indicated by strong association betwe e $\mathrm{n}$ the factors and OMCL. In the case of OMCC, gravel content, percentage fine and cement content showed strong association between the factors and OMCC.

Table 5 Pearson's Coefficients of Correlation for OMC and Geotechnical Properties of Lime and Cement Treated BCS with IOT

\begin{tabular}{|c|c|c|c|c|c|c|c|c|}
\hline & OMCC & $\mathrm{Gr}$ & $\mathrm{Sa}$ & $\mathrm{PF}$ & $\mathrm{PI}$ & Gs & $\mathrm{Li}$ & IOT \\
\hline & & - & & & - & - & & - \\
\hline $\mathrm{OMCL}$ & - & 0.444 & 0.081 & 0.021 & 0.682 & 0.938 & 0.464 & 0.846 \\
\hline \multirow[t]{2}{*}{$\mathrm{Gr}$} & 0.066 & - & 0.086 & 0.143 & 0.012 & 0.314 & 0.035 & 0.410 \\
\hline & & & & - & - & & & \\
\hline \multirow[t]{2}{*}{ Sa } & -0.266 & 0.458 & - & 0.974 & 0.293 & 0.049 & 0.222 & 0.104 \\
\hline & & - & - & & & - & - & - \\
\hline \multirow[t]{2}{*}{$\mathrm{PF}$} & 0.241 & 0.554 & 0.994 & - & 0.288 & 0.121 & 0.229 & 0.197 \\
\hline & & - & & - & & & - & \\
\hline \multirow[t]{2}{*}{ PI } & -0.252 & 0.122 & 0.200 & 0.172 & - & 0.651 & 0.905 & 0.311 \\
\hline & & - & & - & & & - & \\
\hline \multirow[t]{2}{*}{ Gs } & -0.600 & 0.010 & 0.449 & 0.419 & 0.555 & - & 0.395 & 0.891 \\
\hline & & & & - & & & & \\
\hline \multirow[t]{2}{*}{$\mathrm{Ce}$} & 0.023 & 0.297 & 0.650 & 0.646 & 0.580 & 0.530 & - & 0.000 \\
\hline & & - & & & & & & \\
\hline \multirow[t]{2}{*}{ IOT } & -0.690 & 0.261 & 0.004 & 0.029 & 0.513 & 0.764 & 0.000 & - \\
\hline & Low & r diagon & :OMCL; & Upper dia & onal: ON & & & \\
\hline
\end{tabular}

that field compaction specification and control can easily be monitored for BCS treated lime-IOT than cement-IOT treated soil. Thus, a good measure of moisture control can easily be monitored using those variables during field compaction of soillime-IOT treated soil. Based on the Nigerian General Specifications requirements, the $4 \%$ cement / $6 \%$ IOT optimally improved soil did not fulfill the criteria of not greater than $35 \%$ passing sieve No. 200 and $30 \%$ as peak plasticity index value for use as materials for sub-grade. But, an optimal blend of $4 \%$ lime $/ 6 \%$ IOT improved the properties of BCS and met the said criteria. The paybacks of the application include the re-use of a mining waste in road construction and the economy of the proposed technique on the construction cost. 


\section{References}

[1] Chen, F. H: Foundation on Expansive Soils 1988. Elsevier Scientific Pub. Co., Amsterdam.

[2] Nelson, D. and Miller, J. 1992. Expansive Soils: Problems and Practices in Foundation and Pavement Engineering. John Wiley and Sons, Inc. New York.

[3] Warren, K. W. and Kirby, T. M.: Expansive clay soil 2004. A widespread and costly geohazard. Geostrata, Geo-Institute of the American Society Civil Engineers, Jan: 24-28.

[4] Amadi, A.A and Osu, A. S 2018. Effect of curing time on strength development in black cotton soil. Quarry fines composite stabilized with cement kiln dust (CKD). Journal of King Saud University Engineering Sciences. 30(4): 305-312

[5] Nwonu, D.C. and Ikeagwuani, C.C. 2020. Microdust effect on the physical condition and microstructure of tropical black clay. International Journal of Pavement Research and. Technology. https://doi.org/10.1007/s42947-020-0004-5

[6] Osinubi, K. J.: Lime Modification of Black Cotton Soil 1995. Spectrum Journal, Kaduna. 2(1): 112 - 122.

[7] Amadi, A. 2010. Evaluation of changes in Index Properties of Lateritic soil Stabilized with Fly Ash. Leonardo Electronic Journal of Practices and Technologies. $69-78$.

[8] Neville, A.M.: Properties of Concrete. 4th ed. (low-price ed.) 2000. Pearson Education Asia Publication, England, Produced by Longman Malaysia.

[9] Osinubi, K. J. and Stephen, A. T. 2007. Influence of compactive efforts on bagasse ash treated black cotton soil." Nigerian Journal of Soil and Environmental Research. 7: $92-101$.

[10] Osinubi, K. J. Akinmade, O. B. and Eberemu A. O. 2009. Stabilization potential of locust bean waste ash on black cotton soil. Journal of Engineering Research. 14(2):1 - 13 University of Lagos, Nigeria

[11] Kumar S and Prasanna M. 2012. Silica and calcium effect on geotechnical properties of expansive soil extracted from rice husk ash IPCBEE, 32.

[12] Cokca E. 2001. Use of class C fly ashes for the stabilization- of an expansive soil, Journal of Geotechnical and Geoenvironmental Engineering. 127: 568-573.

[13] Salahudeen, A. B., Eberemu, A. O. and Osinubi, K. J. 2014. Assessment of cement kiln dust treated expansive soil for the construction of flexible pavements. Journal of Geotechnical and Geological Engineering, GEGE, Springer International Publishing Switxerland, Online, DOI 10/1007/s10706-014-9769-0. 32:923-931

[14] Osinubi, K. J., Yisa, G. L. and Eberemu, A. O.2014. Compaction behaviour of lateritic soil - iron ore tailing mixtures. Proceedings of 7th International Conference on Environmental Geotechnics, Theme: Lessons, Learning and Challenges, Congress Proceeding e-Book Editors Abdelmalek Bouazza, Sam Yuen, Bruce Brown. 10 - 14 November, Melbourne, Australia. Session 4B-7,1009- 1016.

[15] Osinubi, K. J., Yohanna, P and Eberemu, A. O. 2015. Cement Modification of Tropical Black Clay Using Iron Ore Tailing as Admixture. Journal of Transportation Geotechnics. http://dx.doi.org/10.1016/j.trgeo.2015.10.001 Elsevier Publishing Company. 5: 35-49.

[16] Osinubi, K. J., Eberemu, A. O., Yohanna, P and Etim, R. K. 2016. Reliability Estimate of Compaction Characteristics of Iron Ore Tailings Treated Tropical Black Clay As Road Pavement Sub-Base Material. American Society of Civil Engineers (ASCE) Geotechnical Special Publication. 271: 855-864.

[17] BS 1377.1990.Methods of Testing Soils for Civil Engineering Purposes. British Standard Institution, London.
[18] BS 1924 1990. Methods of Test for Stabilized Soils. British Standards Institute, London.

[19] AASHTO. 1986. Standard Specification for Transportation, Material and Methods of Sampling and Testing. 14th Edition. Amsterdam Association of State Highway and Transportation Officia Washington D.C.

[20] ASTM 1992. Annual Book of Standards Vol. 04.08, American Society for Testing and Materials, Philadelphia.

[21] Czernin, W. 1962. Cement Chemistry and Physics For Civil Engineers, Crosby Lockwood, London.

[22] Osinubi, K. J. 2006. Influence of Compactive Efforts on Lime-slag treated tropical black clay. Journal of Materials in Civil Engineering, ASCE. 18(2): $175-181$.

[23] Ishola, K. 2014. Modification Of Lateritic Soil With Iron Ore Tailing. Unpublished M.Sc. Thesis, Civil Engineering Department, Ahmadu Bello University, Zaria.

[24] Saeid. A, Amin. C, and Hamid. N. 2012. A Review on The Lime and Fly ash Application in Soil Stabilization. International Journal of Biological, Ecological and Environmental Sciences 1, (3): 124-126.

[25] Al-Zoubi, M. S.2008. Undrained Shear Strength and Swelling Characteristics of Cement Treated Soil. Jordan Journal of Civil Engineering, 2(1):53-62.

[26] Etim, R. K., Attah, I. C. and Yohanna, P.2020. Experimental Study on Potential of Oyster Shell Ash in Structural Strength Improvement of Lateritic Soil for Road Construction. International Journal of Pavement Research and Technology. DOI: https://doi.org/ 10.1007/s42947-020-0290-y. 13:341-351

[27] Osinubi, K. J. 1999. Evaluation of admixture stabilization of Nigerian Black Cotton Soil. Nigerian Society of Engineers Technical Transactions. 34(3): $88-96$.

[28] Harichane, K., Ghrici, M., Kenai, S. and Grine, K.2011. Use of Natural Pozzolana and Lime for Stabilization of Cohesive Soils. Journal Of Geotechnical And Geological Engineering. 29(5): 759.

[29] [29] Castro-F, D.,Movilla-Q, D., Vega-Z, Á., and Calzada-Pérez, M. A. 2011. Lime Stabilization of bentonite sludge from tunnel boring. Journal of Applied Clay Science, 51(3), 250-257.

[30] [30]Osinubi, K. J. 2000. Influence of Compaction Energy levels and delays on cement treated soil. Nigerian Society of Engineers Technical Transactions, 36(4)1-11.

[31] [31]Moses, G. 2008. Stabilization of Black Cotton Soil with Ordinary Portland Cement Using Bagasse Ash as Admixture. IRJ Journal of Research in Engrg, 5(3): 107-115.

[32] [32]Oriola, F., and Moses, G. 2010.Groundnut Shell Ash Stabilization of Black Cotton Soil. Electronic Journal of Geotechnical Engineering, 15, 415-428.

[33] [33] Srikanth Reddy, S., Prasad, A. C. S. V. and Vamsi Krishna, N. 2018. Lime-Stabilized Black Cotton Soil and Brick Powder Mixture as Subbase Material.Advances in Ciil Engineering. https://doi.org/10.1155/2018/5834685.

[34] [34] Osinubi, K. J. 2001. Influence of compaction energy levels and delays on cement treated soil.' The Nigerian Society of Engineers Technical Transactions, 36(4) $1-13$.

[35] [35]Moses, G., Saminu, A, and Oriola F.O.P. 2012. Influence of Compactive Efforts on Compacted Foundry Sand Treated With Cement Kiln Dust. Journal of Civil and Environmental Research, 2(5): 11-24.

[36] [36] Nigerian General Specifications 1997. Roads and Bridges.Federal Ministry of Works, Abuja, Nigeria.

[37] [37] Gadzama, E. W., Nuhu, I and Yohanna, P (2017) Influence of Temperature on the Engineering Properties of Selected Tropical Black Clay.Arabian Journal for Science and Engineering.Springer 
International Publishing Switzerland https://doi 10.1007/s13369-017-

2485-3.

[38] [38] Yohanna, P., Oluremi, J.R., Eberemu, A.O.,Osinubi, k.J., Sani, J.E(2018) Reliability Assessment of Bearing Capacity of Cement-Iron Ore Tailing Blend Black Cotton Soil for Strip Foundations. Journal of
Geotechnical and Geological https://doi.org/10.1007/s10706-018-0660-2.
Engineering. 